\title{
LEAF TEMPERATURE AND TRANSPIRATION OF PEQUI TREES WITH AND WITHOUT WATER RESTRICTION
}

\author{
Raiane F. Miranda ${ }^{*}$, José Alves Júnior², Derblai Casaroli², Adão W. P. Evangelista ${ }^{2}$, \\ Rafael Batisti ${ }^{2}$
}

1* Corresponding author. Instituto Federal do Norte de Minas Gerais/ Almenara - MG, Brasil.
E-mail: araianemiranda@gmail.com | ORCID ID: https://orcid.org/0000-0002-8762-3061.

\author{
KEYWORDS \\ Caryocar brasiliense \\ Camb., water \\ requirement, water \\ deficit, Brazilian \\ Savannah
}

\begin{abstract}
The answers to when and how much to irrigate orchards can be obtained based on the measurements of plants' transpiration and leaf temperature. This study aims to determine the leaf temperature and sap flow of the pequi tree (Caryocar brasiliense Camb.), both with and without water restriction. Further, the leaf temperature was measured by infrared thermometry and estimated transpiration using the Granier method, where the thermal dissipation probes are inserted into the plant stems. The experiment was conducted in a 120-plant orchard located in Goiânia-GO, Brazil, from which seven of the plants (3 irrigated and 4 non-irrigated; aged 6.6-7.4 years) were evaluated for eight months (October 2015 to May 2016). The soil was characterized as a dystrophic red latosol, and its water content was determined using the EC-5 capacitance sensors. The results denoted that the leaf temperature of the irrigated plants was lower than the median air temperature during summer and the transition period into the dry season, and the non-irrigated plants exhibited shortage of water availability during the dry season. In dryland conditions, the average transpiration was $24.09 \mathrm{~L} \mathrm{plant}^{-1}$ day $^{-1}$ and, when irrigated, became $42.29 \mathrm{~L}$ plant $^{-1}$ day $^{-1}$.
\end{abstract}

\section{INTRODUCTION}

Cerrado, the Brazilian Savannah, is characterized by acid soils that exhibit low natural fertility and high water deficit throughout the dry season, which occurs between May and September. Therefore, native plants have evolved to develop mechanisms of adaptation to water deficit conditions. A previous study denoted that native plants control transpiration via pronounced stomatal control, leading to limitations on sap flow, leaf water potential, and stomatal conductance during both the dry and rainy seasons (Meinzer et al., 1999).

Among the fruit trees native to Cerrado biome, the pequi tree (Caryocar brasiliense Camb.) stands out because of the potential for industrial use of its fruit, seed, leaves, and bark (Gomes et al., 2015; Almeida et al., 2015; Pinto et al., 2016). However, its commercial usage is still limited, and extractivism is predominant. This can be partially attributed to its long early growth period, with production beginning only between the age of eight to ten years old, which poses an obstacle to expand cultivation for commercial purposes (Alves Júnior., et al., 2013, 2015; Miranda et al., 2016).
In case of commercial fruit production, irrigation is used to ensure the quality and productivity of orchards as well as to achieve off-season production (Vasconcelos et al., 2013; Lima et al., 2014; Amorim et al., 2015). Comparing the pequi tree with other trees grown regionally, it can be observed to grow under water deficit conditions owing to its early reproductive period; additionally, it can provide fruits exhibiting improved physic-chemical and nutritional qualities throughout the year. However, there is a lack of information related to the irrigated pequi trees concerning their water regulation behavior under water scarcity and availability.

To understand the water-related characteristics of a crop, it is essential to know its physiological responses to environmental stimuli. The transpiration measures and leaf temperature can help in this regard. If measured, the correlation between the sap flow and leaf surface transpiration can help to estimate the transpiration of woody species, allowing long-term monitoring of the water-related properties under non-disturbed natural conditions (Vellame et al., 2012). The leaf temperature can indicate if the plant is under water stress when the temperature becomes greater

\footnotetext{
${ }^{2}$ Universidade Federal de Goiás/ Goiânia - GO, Brasil.

Received in: 1-29-2018

Accepted in: 7-31-2019
} 
than the average air temperature (Trentin et al., 2011; Thapa et al., 2018).

The objective of this study was to determine the leaf temperature and sap flow of the pequi tree (Caryocar brasiliense Camb.) under water scarcity and availability conditions.

\section{MATERIAL AND METHODS}

The study was conducted in an experimental pequi orchard located at the School of Agronomy of the Federal University of Goiás, Goiânia $\left(16^{\circ} 35^{\prime} 12^{\prime \prime} \mathrm{S}, 49^{\circ} 21^{\prime} 14^{\prime \prime} \mathrm{W}\right.$, $730 \mathrm{~m})$. According to Köppen-Geiger climate classification, the regional climate belongs to the Aw category, with dry winters and rainy summers. The soil of the area was classified as dystrophic red latosol exhibiting a franco clay texture. The chemical analysis of the soil before plantation denoted the following properties: $\mathrm{pH}: 4.7$ $\left(\mathrm{CaCl}_{2}\right) ; \mathrm{Al}^{3+}: 0.0 \mathrm{cmol}_{\mathrm{e}} \mathrm{dm}^{-3}$; organic material: $1.5 \mathrm{~g} \mathrm{dm}^{-3}$; P: $1.7 \mathrm{mg} \mathrm{dm}{ }^{-3} ; \mathrm{K}^{+}: 60 \mathrm{mg} \mathrm{dm}{ }^{-3} ; \mathrm{Ca}^{2+}: 10 \mathrm{cmol}_{\mathrm{e}} \mathrm{dm}^{-3}$; $\mathrm{Mg}^{2+}$ : $4.0 \mathrm{cmol}_{\mathrm{e}} \mathrm{dm}^{-3}$; $\left(\mathrm{H}^{+} \mathrm{Al}^{3+}\right): 43.0 \mathrm{cmol} \mathrm{dm}^{-3}$; cation exchange capacity (CTC): $59.0 \mathrm{cmol} \mathrm{dm}^{-3}$; and base saturation $(\mathrm{V} \%)$ : $26.5 \%$. The particle size distribution analysis indicated that the soil comprises $31 \%, 23 \%$, and $46 \%$ of sand, silt, and clay, respectively.

The orchard was established in 2009 when 120 pequi seedlings were transplanted in a $5 \times 5$-m grid. Since the transplantation was completed, the plants have been subjected to water scarcity and availability conditions. In case of irrigated plants, the aim was to provide sufficient water for replenishing the water lost because of evapotranspiration (ETc). Therefore, the irrigated water volume (using a micro-sprinkler) was calculated from the $\mathrm{ET}_{0}$ product (Allen et al., 2006), and the crop coefficient $\left(\mathrm{K}_{\mathrm{c}}\right)$ was considered to be 0.9 , representative of fruit trees having a similar age and grown in an identical spacing to those of the pequi trees (Allen et al., 2006). During the dry period, irrigation was conducted weekly, and $100 \%$ of the ETc was replenished. Agrometeorological variables were obtained from the School of Agronomy of the Federal University of Goiás, EA/UFG (College of Agronomy Federal University of Goiás) automatic station (HOBO), located $350 \mathrm{~m}$ away from the experimental orchard.

From the study area, seven pequi trees were selected (three irrigated and four non-irrigated) to evaluate their sap flow and leaf temperature. Further, the soil water content for the irrigated plants as well as for plants subjected to dryland conditions was monitored.

To do so, two batteries of $\mathrm{ECH}_{2} \mathrm{O}$ sensors (model: EC-5, brand: Decagon) were installed under the canopy projection ( $0.50 \mathrm{~m}$ from the stem) of two pequi trees, one under water availability and one under water scarcity. The sensors were installed at depths of $0.50,1.00,1.50,2.00$, and $2.50 \mathrm{~m}$ and connected to the Em50 datalogger (Brand: Decagon). Readings were taken on an hourly basis from October 2015 to May 2016. To adjust the soil water retention curve, 15 undisturbed soil samples were collected at the same depths at which the EC-5 sensor was installed $(0.50,1.00,1.50,2.00$, and $2.50 \mathrm{~m})$. They were subsequently saturated, centrifuged, and subjected to rotations equivalent to $-6,-8,-10,-33,-60,-100$, and $-1.500 \mathrm{kPa}$ tensions (Freitas Júnior \& Silva, 1984).

The data were adjusted to Van Genuchten's model (1980) using the SWRC software (Dourado Neto, 1990), and the tensions were adjusted for water content under a field capacity and permanent wilting point of -10 and $-1500 \mathrm{kPa}$, respectively.

The leaf temperature was measured using a digital infrared laser thermometer (brand: Fluke, model: 59 max + ). Readings were taken in the morning from 08:00 to 10:00 from three irrigated and four non-irrigated tree samples. The leaf temperature values obtained using the thermometer were compared with the average air temperature provided by the EA/UFG agrometeorological station during the measurements. A leaf temperature greater than the average air temperature indicated that the plant was under water stress (water scarcity) (Trentin et al., 2011).

The xylem sap flow density was estimated daily between October 2015 and May 2016 using a thermal dissipation probe proposed by Granier (1987). The measurement was conducted by perpendicularly inserting a pair of probes located $0.10 \mathrm{~m}$ apart and aligned with the vertical trunk. The upper end of the probe was heated by a constant electrical power of $0.1 \mathrm{~W} \mathrm{~cm} \mathrm{~cm}^{-1}$. Further, the temperature gradient between the two probes can be determined based on the convective heat transportation within the sap. The occurrence of maximum temperature difference between the two probes during a particular period indicates minimal or nil sap flow rate, whereas the occurrence of minimum temperature difference indicates maximum sap flow rate through this conductive stem section (Granier, 1987);

In September 2015, seven thermal dissipation probe pairs were installed on seven pequi trees (among which three irrigated pequi trees represented the water availability condition, whereas the remaining four trees represented the water scarcity condition). The probes were $1.0 \mathrm{~cm}$ in length and were made of $1.0-\mathrm{mm}$ diameter needles. The temperature gradient between the two probes was measured using a copper-constantan thermocouple $(0.5 \mathrm{~mm}$ in diameter) inserted inside the probes and filled with hot glue. The heat-dissipating probe was manufactured using a constantan wire wrapped around the needle (34 turns) to form a resistor to which a power of $0.1 \mathrm{~W} \mathrm{~cm}^{-1}$ was applied, as recommended in the literature (Granier, 1987) (Figure 1).

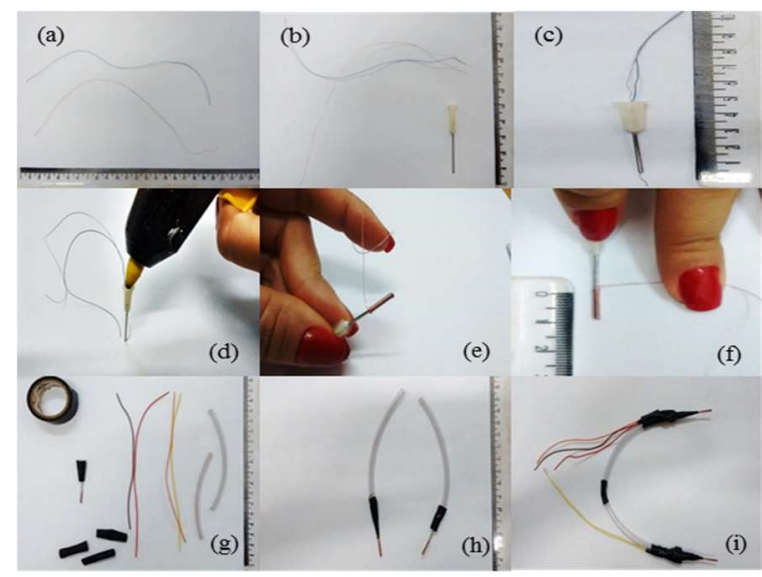

FIGURE 1. Details for developing heat dissipation probes. Copper and constantan wire (a), copper-constantan thermocouple and needle (b), thermocouple installation on the needle (c), probe filling for thermocouple fixation (d), constantan resistor of the heated probe (e), resistor's length (f), materials used for building the probe (g), disconnected probe edges (h) and completed probe (i). 
The Granier method, which estimates the sap flow (F), assumes that the stem conductive section (AS) area is known. Therefore, the monthly stem perimeter variation was related to the area of the conductive section by removing the stem bark surface measured by a bark meter (brand: SoilControl, model: MCA-100, specifications: thickness determined to be between 0 and $50 \mathrm{~mm}$ ).

The sap flow density $\left(\mathrm{m}^{3} \mathrm{~s}^{-1}\right)$ was obtained based on the adjusted empirical relation (Equation 1) for woody species (Granier, 1987).

$$
F=118,99 \cdot 10^{-6} \cdot k^{1,231} \cdot A S
$$

Where,

AS corresponds to the effective section area of the stem that conducts raw sap $\left(\mathrm{m}^{2}\right)$, and

$\mathrm{K}$ is the heat dissipation coefficient obtained as follows:

$$
K=\frac{\left(\Delta T_{\operatorname{máx}}-\Delta T\right)}{\Delta T_{\operatorname{máx}}}
$$

Where,

$\Delta$ Tmax is the maximum temperature difference when the sap flow is zero, and

$\Delta \mathrm{T}$ is the temperature difference when the sap flow differs from zero.

Prior to the installation of probe into the trunk, an aluminum capsule filled with a high-conductivity thermal paste (Dow Corning4, Dow Corning Corporation) was inserted to homogenize the heat around the probe and optimize the contact between the heat source and thermocouples using the stem. After installation, the probes were foil-wrapped to reduce the radiation effect via measurements (Figure 2).

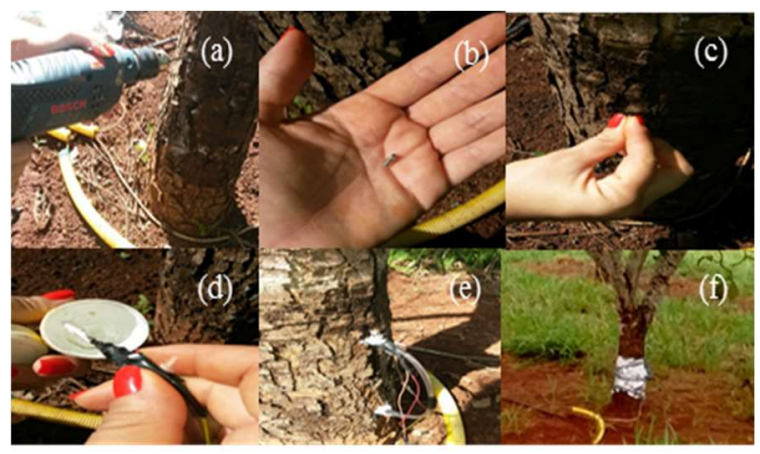

FIGURE 2. Installation of the thermal dissipation probes on the pequi trees grown in Goiânia-GO in 2016. Stem drilling $0.15 \mathrm{~m}$ above the ground (a), aluminum capsule (b), capsule insertion into the trunk (c), probe coating with thermal paste (d), installed probe (e), and stem coating with laminated paper (f).
A power charge of $0.1 \mathrm{~W} \mathrm{~cm}^{-1}$ was not supplied to one of the probes installed on the plants under dryland condition, and it only recorded the plants' natural thermal difference of sap flow. The probe values were correlated with the others to generate estimation models of the natural thermal difference for each segment of the monitored stem (Equation 3). The natural thermal differences were obtained on $11 / 14 / 2015,12 / 9 / 2015,02 / 09 / 2016$, and $05 / 30 / 2016$ when the probe heating was turned off.

$$
D T N_{E=} a \cdot D T N_{\text {ref }}+B
$$

Where,

$\mathrm{DTN}_{\mathrm{E}}$ is the estimated natural thermal difference for each probe $\left({ }^{\circ} \mathrm{C}\right)$;

$\mathrm{DTN}_{\text {ref }}$ is the natural thermal difference of the reference probe $\left({ }^{\circ} \mathrm{C}\right)$, and

$a$ and $b$ are empirical coefficients.

The thermal difference of the heated probe was corrected using [eq. (4)].

$$
\Delta T=\Delta T_{m}-D T N_{E}
$$

Where,

$\Delta \mathrm{T}$ is the corrected current thermal difference $\left({ }^{\circ} \mathrm{C}\right)$, and

$\Delta \mathrm{Tm}$ is the uncorrected thermal difference $\left({ }^{\circ} \mathrm{C}\right)$.

The thermal difference measurements were conducted every $30 \mathrm{~s}$, and the reading averages were recorded every $15 \mathrm{~min}$ using a data logger (CR 21X Campbell SCi datalogger).

The leaf temperature and sap flow medians were compared using the Student's t-test, with those differing between themselves at a probability level of $\mathrm{P}<0.05$ being considered as significant.

\section{RESULTS AND DISCUSSION}

Figure 3 depicts the monitoring of soil water content from October 2015 to May 2016. It shows that the soil water content replenished by irrigation and precipitation varied with respect to the field capacity $\left(\theta_{\mathrm{cc}}\right)$ and critical moisture $\left(\theta_{\text {crit }}\right)$ only at a depth of $0.50 \mathrm{~m}$ (under the irrigated canopy). At a depth of $1.00 \mathrm{~m}$, the water content was lower than the permanent wilting point $\left(\theta_{\mathrm{pmp}}\right)$, regardless of irrigation. At a depth of $2.00 \mathrm{~m}$, this content was lower than $\theta_{\text {pmp }}$, whereas the soil water content became lower than $\theta_{\text {crit }}$ despite not being lower than $\theta_{\text {pmp }}$ throughout the evaluation period at a depth of $2.50 \mathrm{~m}$. 


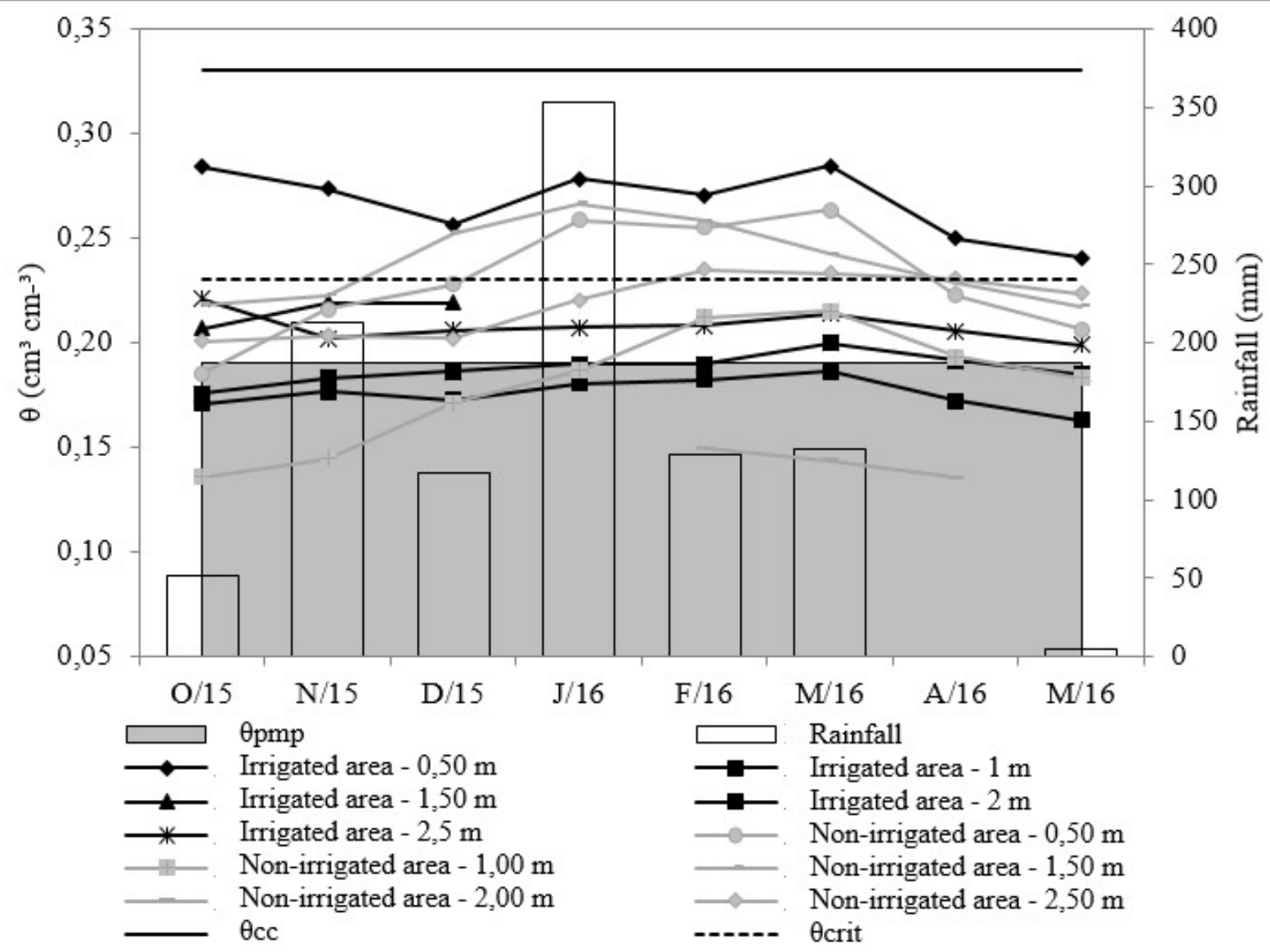

FIGURE 3. Soil water content and rainfall in the irrigated and non-irrigated area in the pequi experimental orchard at the School of Agronomy, Federal University of Goiás, Goiânia-GO (2015-2016).

At a depth of $0.50 \mathrm{~m}$ in the non-irrigated area, the soil water content remained lower than $\theta_{\text {pmp }}\left(0.33 \mathrm{~cm}^{3} \mathrm{~cm}^{-3}\right)$ until October 2015; subsequently, it became greater than $\theta_{\text {crit }}(0.23$ $\mathrm{cm}^{3} \mathrm{~cm}^{-3}$ ) because of precipitation and decreased again until April 2016. Thereafter, it remained lower than $\theta_{\text {crit. }}$

A similar behavior was observed at a depth of 1.00 $\mathrm{m}$. However, precipitation increased the soil water content just above $\theta_{\text {pmp }}\left(0.19 \mathrm{~cm}^{3} \mathrm{~cm}^{-3}\right)$ between February and April 2016. For depths of 1.50 and $2.50 \mathrm{~m}$, the soil water content, despite being lower than $\theta_{\text {pmp }}$ until September 2015, increased and became greater than $\theta_{\text {crit }}$ with the onset of the rainy season in October of the same year, December 2015 to April 2016 for 1.5-m depths, and February to April for 2.50-m depths.

Therefore, irrigation mainly contributed to the water content in the topsoil $(0.50 \mathrm{~m})$. During the dry season (April and May 2016), the soil water content was almost critical (soil water availability factor $=0.7$ ) despite irrigation. Evaluation of the leaf temperature during this period showed that plants suffered from water stress, which ended in May with the onset of irrigation (Figure 4).

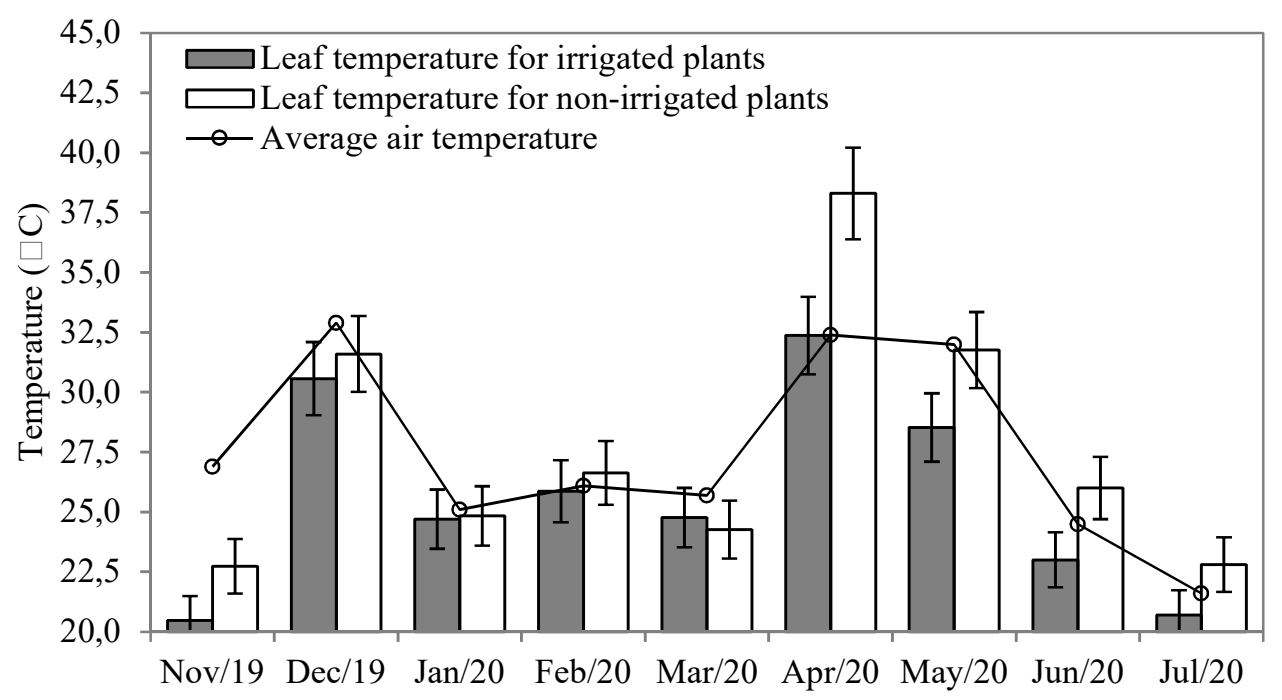

FIGURE 4. Average air and leaf temperatures of the pequi trees, grown in an experimental orchard at the School of Agronomy, Federal University of Goiás, Goiânia-GO (2016), with ages of 6.10 to 7.6 years, when irrigated and not irrigated. 
During the rainy season (October 2015 until April 2016; Figure 4), there was no evidence of water stress in pequi trees $(\mathrm{P}<0.05)$. However, from mid-April and throughout the transition period between dry and rainy seasons in the Savannah of Goiá, the non-irrigated plants were under water stress (Figure 4). In this month, the leaf temperature of the non-irrigated plants was $5.90^{\circ} \mathrm{C}$ higher than the average air temperature. Further, rainfall was observed to be insufficient for preventing the non-irrigated plants from being under water stress during the initial dry months (May-June 2016) (Figure 4). In June and July, the thermal gradients between the leaf and air average temperatures were $1.20^{\circ} \mathrm{C}$ and $1.50^{\circ} \mathrm{C}$, respectively. With irrigation, the average thermal gradient became $-2.00^{\circ} \mathrm{C}$.

Although the usage of leaf temperature as an indicator of water stress is a widespread practice (Trentin et al., 2011; Giorio et al., 2012; Khatun et al.; 2015; Brunini $\&$ Turco, 2016), the gradient value based on which physiological changes occur in a plant has been rarely discussed because this information is directly dependent on the sensitivity of the plant to water deficit. Water loss by leaves occurs through water pore diffusion via stomata pores. When the soil water is less abundant, the stomata opens less or remains closed to avoid plant wilting, leading to high leaf temperatures and low sap flow in the xylem (Taiz \& Zeiger, 2004). Assessments complementary to leaf temperature, such as sap flow assessments, are important.

During the rainy season (Julian days 121 to 277), no difference $(\mathrm{P}<0.05)$ was observed in the daily course of sap flow in case of irrigated and non-irrigated plants, with values of 39.30 and $23.29 \mathrm{~L}_{\text {day }}{ }^{-1}$ plant $^{-1}$, respectively. With the onset of the dry season (Julian days 92 to 141), a difference in sap flow can be observed $(\mathrm{P}<$ $0.05)$. Irrigated plants' sap flow was $64.26 \mathrm{~L} \mathrm{day}^{-1}$ plant $^{-1}$, decreasing to become $29.06 \mathrm{~L} \mathrm{day}^{-1}$ plant $^{-1}$ for the nonirrigated ones (Figure 5).

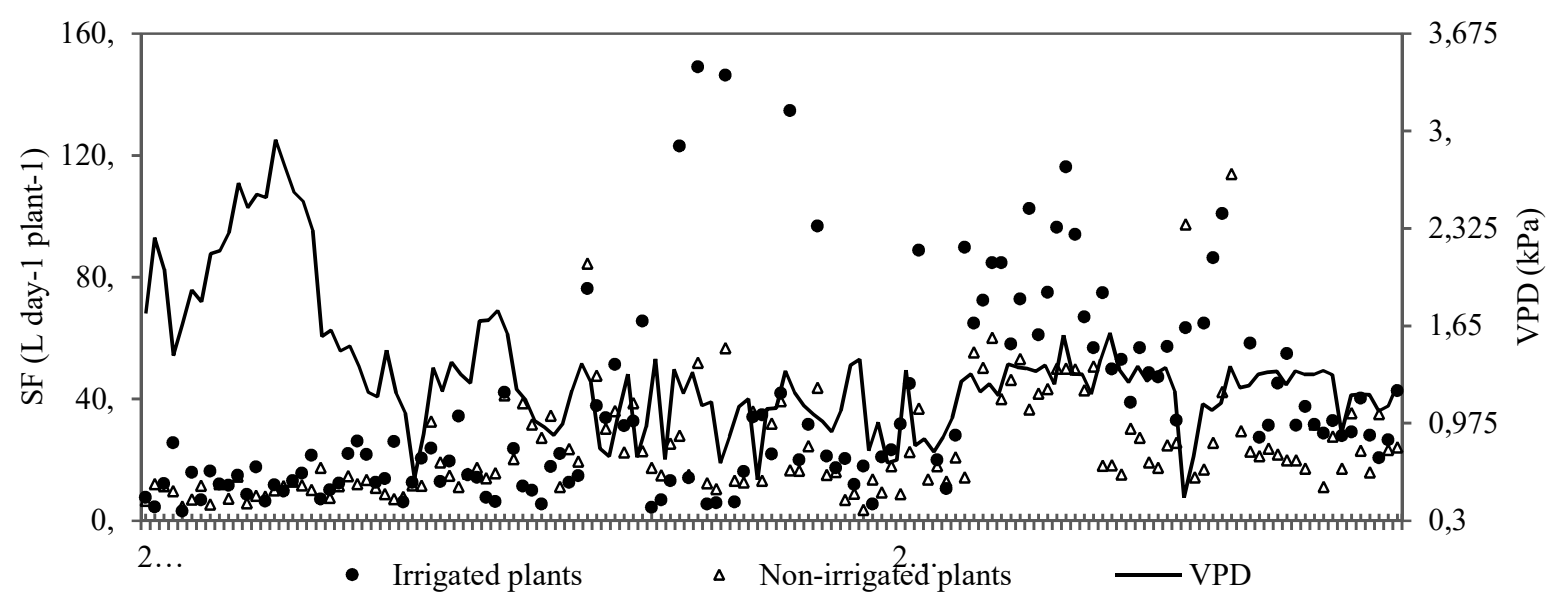

FIGURE 5. Vapor pressure deficit (VPD) and mean sap flow (SF) in irrigated and non-irrigated plants with ages of 6.6 to 7.4 years grown in an experimental orchard at the School of Agronomy, Federal University of Goiás, Goiânia-GO (2015-2016).

Raw sap flow (SF) is associated with plant transpiration. To obtain SF, there must be tension over water in the xylem (main cell of water transport in vascular plants) caused by transpiration (Pimentel, 2004). For the entire evaluation period (Julian days 142 to 277), the average orchard transpiration was 42.79 and $24.09 \mathrm{~L} \mathrm{day}^{-1}$ plant $^{-1}$ for the irrigated and non-irrigated plants, respectively. Thus, if watered, the pequi trees exhibit approximately $56 \%$ more transpiration when compared with that under normal Cerrado conditions during the rainy season and the beginning of the dry season.

$\mathrm{SF}$ reduction is a physiological mechanism that is used by the tree to protect itself from water scarcity. When there is abundant water in the soil and incident solar radiation on leaves favors high photosynthetic activity, the demand for $\mathrm{CO}_{2}$ within the leaf is large and the stomatal pores remain wide open, decreasing the stomatal resistance to $\mathrm{CO}_{2}$ diffusion. However, in case of scarce water supply, the plant advantageously alternates water with photosynthetic products essential for its growth and reproduction (Taiz \& Zeiger, 2004). In such conditions, the transpiration of plants reduces.

By analyzing the course of SF for ten consecutive days during the rainy and dry periods (Figure 6), the average SF was observed to be $2.50 \mathrm{~L} \mathrm{~h}^{-1}$ in irrigated plants (Figure 6 a), approximately $69 \%$ higher than that in the nonirrigated plants $\left(1.73 \mathrm{~L} \mathrm{~h}^{-1}\right)$ (Figure $6 \mathrm{~b}$ ). This indicates that soil water replenishment by precipitation during the Cerrado's rainy period (from October to April) is unable to increase the SF values to levels similar to those of an irrigated plant. 

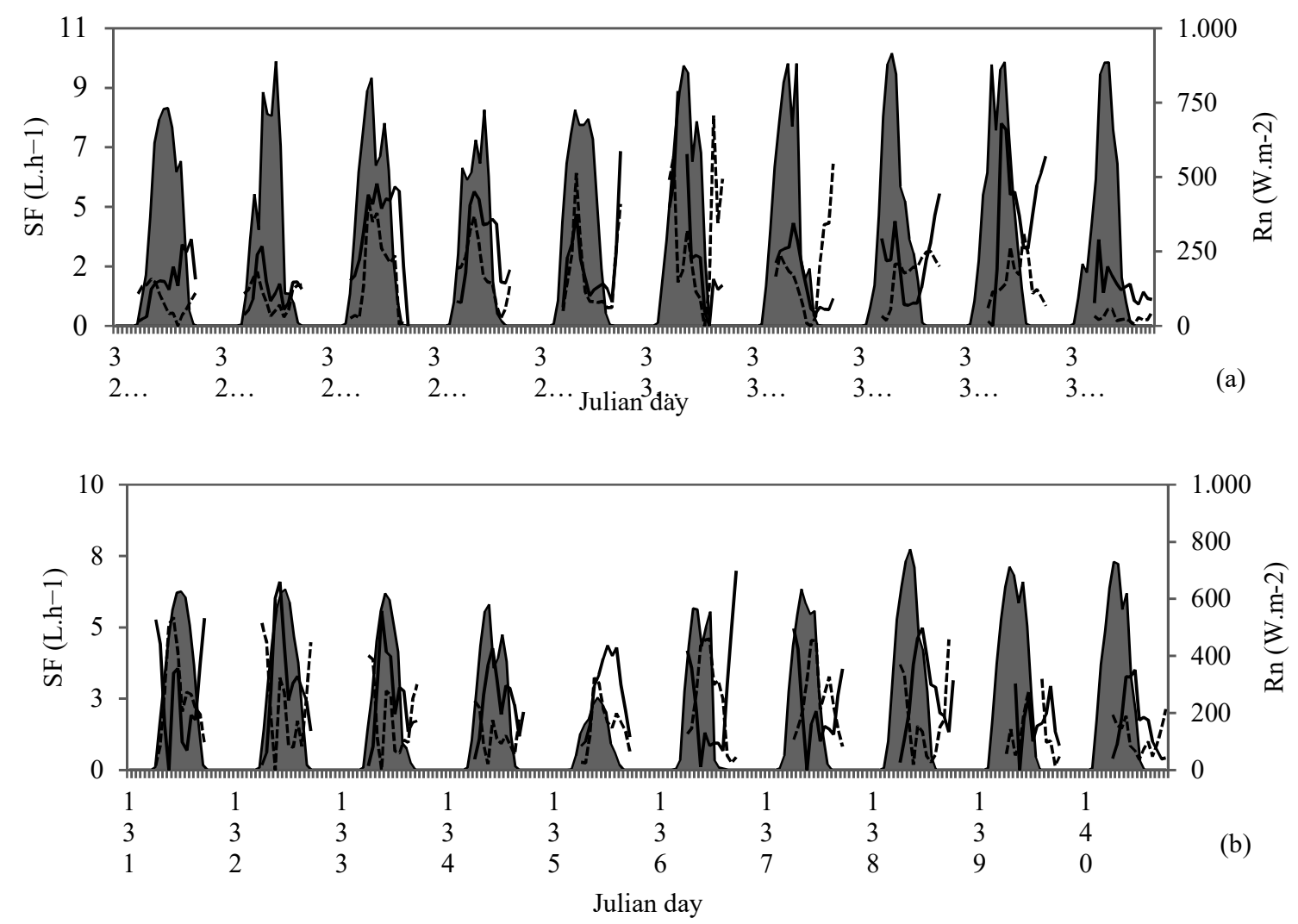

Solar radiation

Drylands' condition

Irrigation

FIGURE 6. Solar radiation (Rn) and mean sap flow (SF) of the irrigated and non-irrigated pequi trees with ages of 6.6 to 7.2 years over ten consecutive days during the rainy (a) and dry (b) periods, cultivated at the School of Agronomy's experimental orchard, Federal University of Goiás, Goiânia-GO (2015-2016).

Furthermore, there is a lag associated with the course of SF and solar radiation. This behavior can be attributed to the continuity of SF, even in case of minimal radiation, and aims to replenish the water lost through the plant tissue throughout the day. The latter was also observed by other authors (Delgado-Rojas et al., 2006; Sérvulo et al., 2017).

In periods of high atmospheric demand without water availability to the roots, the course of SF tends to remain stable due to the influence of stomata on the transpiratory flow (Barbiero et al. 2000). The course of SF in the non-irrigated pequi trees was unstable (Figures 6a and $6 b)$. Even on days of high atmospheric demand and during the dry season, plants continued transpiring.

One possible explanation for this may lie in the expansion of the root system into the soil, which is a common trait among native Savannah plants (Lima et al., 2015). Water movement takes place through the root system because of the difference in water potential between the soil solution on the root surface and xylem sap (Kerbauy, 2004). Thus, when deprived of water, plants will develop a root system that will absorb water to satisfy the water potential gradient. As depicted in Figure 3, during dry periods, the plant roots penetrated the moist soil layers to capture the water from deep layers while maintaining transpiration.

Given that the pequi tree is a perennial and longcycle crop, further studies are required to evaluate the effect of irrigation not only on plant physiology but also on its reproductive phase (both in terms of production and fruit quality).

\section{CONCLUSIONS}

Owing to irrigation, the leaf temperature denoted that plants were not under water stress, even on days of high atmospheric demand, during the dry season (April to September). Irrigation influences the transpiration of the pequi tree. On an average, plants aged 6.6 to 7.4 years old transpired 24.09 and $42.29 \mathrm{~L} \mathrm{plant}^{-1}$ day $^{-1}$ under water availability and scarcity conditions, respectively. Rainfall alone (in Cerrado during the Goiás rainy season from October to April) is unable to increase the SF values to levels similar to those of a plant irrigated during drought.

\section{REFERENCES}

Allen RG, Pereira LS, Raes D, Smith M (2006)

Evapotranspiración del cultivo: Guías para la determinación de los requerimientos de agua de los cultivos. Irrigation and Drainage Paper 56. Rome: FAO, 298p.

Alves Júnior J, Taveira MR, Casaroli D, Evangelista AWP, Vellame LM, Leandro WM (2015) Respostas do pequizeiro à irrigação e adubação orgânica. Global Science and Technology 8(1):47-60. DOI:

http://dx.doi.org/10.14688/1984-3801/gst.v8n1p47-60

Alves Júnior J, Taveira MR, Casaroli D, Evangelista AWP, Barboza LHA (2013) Crescimento de plantas jovens de pequizeiro irrigadas na região do cerrado. Revista Agrotecnologia 4(1):58-73. 
Almeida AN, Bittencourt AM, Santos AJ, Loyola EC, Souza VS (2015) Production and price evolution of the main extractive non timber forest products in Brazil. Revista Cerne 15(3):282-287.

Amorim DA, Rozane DE, Souza HA, Modesto VC, Natale W (2015) Adubação nitrogenada e potássica em goiabeiras 'paluma': I. Efeito na produtividade e na qualidade dos frutos para industrialização. Revista Brasileira de Fruticultura 37(1):201-209. DOI: http://dx.doi.org/10.1590/0100-2945-051/14

Barbiero NCC, Franco AC, Bucci SJ, Goldstein G (2000) Fluxo de seiva e condutância estomática de duas espécies lenhosas sempre-verdes no campo sujo e cerradão. Revista Brasileira de Fisiologia Vegetal 12(2):119-134.

Brunini RG, Turco JEP (2016) Water stress indices for the sugarcane crop on different irrigated surfaces. Revista Brasileira de Engenharia Agrícola e Ambiental 20(10):925-929, 2016. DOI: http://dx.doi.org/10.1590/18071929/agriambi.v20n10p925-929

Delgado-Rojas JS, Righi CA, Karasawa S, Angelocci LR, Bernardes MS, Folegatti MV (2006) Desempenho do método de dissipação térmica na medida do fluxo de seiva em seringueira. Engenharia Agrícola 26(3):722-729.

Dourado Neto D, Jong Van Lier QD, Botrel TA, Libardi PL (1990) Programa para confecção da curva de retenção de água no solo utilizando o modelo de Genuchten. Engenharia Rural 1(2):92-102.

Freitas Júnior E, Silva EM (1984) Uso da centrífuga para determinação da curva de retenção de água do solo, em uma única operação. Pesquisa Agropecuária Brasileira 19(11):1423-1428.

Giorio P, Nuzzo V, Guida G, Albrizio R (2012) Black leaf-clips of a commercial fluorometer increased leaf temperature during dark adaptation under high solar radiation. Irrigation Science 50(3):467-471. DOI: http://dx.doi.org/10.1007/s1 1099-012-0042-6

Gomes SO, Silva RAO, Marques LGA, Santos MRDMC (2015) Prospecção tecnológica: potencialidades de uso do pequizeiro (Caryocar spp.). Revista GEINTEC-Gestão, Inovação e Tecnologias 5(1):1617-1625. DOI: http://dx.doi.org/10.7198/S2237-0722201500010002

Granier A (1987) Evaluation of transpiration in a Douglasfir stand by means of sap flow measurements. Tree physiology 3(4):309-320.

Kerbauy GB (2004) Fisiologia vegetal. Rio de Janeiro, Guanabara Koogan, 452p.

Khatun S, Ahmed JU, Mohi-Ud-Din M (2015) Variation of wheat cultivars in their relationship between seed reserve utilization and leaf temperature under elevated temperature. Irrigation Science 18(2):97-101. DOI: http://dx.doi.org/10.1007/s12892-014-0117-y

Lima GX, Alves Júnior J, Souza JMF, Casaroli D, Evangelista AWP (2015) Distribuição radicular de pequizeiro (Caryocar brasiliense Camb.). Revista Agrotecnologia 6(1):45-54.
Lima CF, Marinho CS, Costa ES, Amaral CO (2014)

Qualidade dos frutos e eficiência produtiva da laranjeira 'Lima' enxertada sobre 'Trifoliata', em cultivo irrigado. Brazilian Journal of Agricultural Sciences 9(3):401-405. DOI:

http://dx.doi.org/10.5039/agraria.v9i3a4433

Miranda RF, Alves Júnior J, Lima GX, Casaroli D, Evangelista AWP, Mesquita M (2016) Crescimento do pequizeiro em resposta a irrigação e adubação. Cultura Agronômica 25(4):351-360.

Meinzer FC, Goldstein G, Franco AC, Bustamante M, Igler E, Jackson P, Caldas L, Rundel PW (1999) Atmospheric and hydraulic limitations on transpiration in Brazilian cerrado woody species. Functional Ecology 13(1):273-282.

Pimentel C (2004) A relação da planta com a água. Seropédica, EDUR, 191 p.

Pinto LCL, Morais LMO, Guimarães AQ, Almada ED, Barbosa PM, Drumond, MA (2016) Traditional knowledge and uses of the Caryocar brasiliense Cambess. (Pequi) by "quilombolas" of Minas Gerais, Brazil: subsidies for sustainable management. Brazilian Journal of Biology 76(2):511-519. DOI: http://dx.doi.org/10.1590/15196984.22914

Sérvulo ACO, Vellame LM, Casaroli D, Alves Júnior J, Souza PH (2017) African Mahogany transpiration with Granier method and water table lysimeter. Revista Brasileira de Engenharia Agrícola e Ambiental 21(5):322326. DOI: http://dx.doi.org/10.1590/18071929/agriambi.v21n5p322-326

Taiz L; Zeiger E (2004) Fisiologia vegetal. 3. ed. Porto Alegre, Artmed, 3 ed. 722p.

Thapa S, Jessup KE, Pradhan GP, Rudd JC, Liu S, Mahan JR, Devkota RN, Baker JA, Xue Q (2018) Canopy temperature depression at grain filling correlates to winter wheat yield in the U.S. Southern High Plains. Field Crops Research 217(1):11-19. DOI:

https://doi.org/10.1016/j.fcr.2017.12.005

Trentin R, Zolnier S, Ribeiro A, Steidle Neto AJ (2011) Transpiração e temperatura foliar da cana-de-açúcar sob diferentes valores de potencial matricial. Engenharia Agrícola 31(6):1085-1095. DOI: http://dx.doi.org/10.1590/S0100-69162011000600006

van Genuchten MT (1980) A closed-form equation for predicting the hydraulic conductivity of unsaturated soils. Soil science society of America journal 44(5):892-898.

Vasconcelos DV, Sousa VF, Araújo TV, Azevedo BM, Sousa GG, Cavalcante Júnior JAHC (2013) Interação entre níveis de irrigação e fertirrigação potássica na cultura do maracujazeiro. Revista Irriga 18(1):160-170. DOI: http://dx.doi.org/10.15809/irriga.2013v18n1p160

Vellame LM, Coelho RD, Tolentino JB (2012) Transpiração de plantas jovens de laranjeira "Valência" sob porta-enxerto limão "Cravo" e citrumelo "Swingle" em dois tipos de solo. Revista Brasileira de Fruticultura 34(1):1-9. DOI: http://dx.doi.org/10.1590/S010029452012000100006 